\title{
Kedudukan Dewan Kehormatan Penyelenggara Pemilu Sebagai Lembaga Quasi Peradilan Etik
}

\section{Position of the Election Organizing Honorary Council As a Quasi Judicial Ethics Institute}

\author{
Harmoko M.Said* \\ Peneliti Komisi Kepolisian Nasional Republik Indonesia \\ harmokomsaid@gmail.com
}

Abstrak: Penelitian ini merupakan penelitian hukum dengan kajian Kedudukan Dewan Kehormatan Penyelenggara Pemilu Sebagai Lembaga Quasi Peradilan Etik. Tujuan penelitian ini adalah untuk mengetahui kedudukan DKPP sebagai lembaga quasi peradilan etik. Metode yang digunakan dalam penelitian ini adalah penelitian hukum normatif. penelitian ini menyimpulkan bahwa kedudukan DKPP sebagai lembaga quasi peradilan etik khusus untuk penyelenggara pemilu yaitu Bawaslu, dan KPU, akan tetapi kedudukannya tidak berada di bawah kekuasaan kehakiman, hal ini dipertegas oleh Mahkamah Konstitusi dalam putusan nomor 115/PHPU.DXI/2013 bahwa DKPP adalah salah satu organ tata usaha negara bukan bagian dari penyelenggara kekuasaan kehakiman yang diatur dalam Pasal 24 ayat (2) UUD 1945, dan bukan pula pengadilan khusus sebagaimana dalam penjelasan Pasal 27 ayat (1) UU Nomor 48 Tahun 2009. Dalam struktur lembaga negara kedudukan DKPP adalah sebagai Cabang kekuasaan keempat yang dimaknai sebagai lembaga negara independen, karena keberadaannya tidak berada dalam ranah cabang kekuasaan legislatif, eksekutif, ataupun cabang yudisial

Kata Kunci: Kedudukan; DKPP; Quasi Peradilan Etik

Abstract: $\quad$ This research is a legal research with a study on the position of the Honorary Board of Election Organizers as a Quasi Ethical 
Court Institution. The purpose of this study was to determine the position of DKPP as a quasi-ethical judicial institution. The method used in this research is normative legal research. This study concludes that the position of DKPP as a quasi-judicial institution of ethics specifically for election organizers, namely Bawaslu, and KPU, but its position is not under judicial power, this is confirmed by the Constitutional Court in its decision number 115/PHPU.D-XI/2013 that DKPP is one of the state administrative organs not part of the judiciary authority as regulated in Article 24 paragraph (2) of the 1945 Constitution, nor is it a special court as described in Article 27 paragraph (1) of Law Number 48 of 2009. In the structure of state institutions The position of DKPP is as the fourth branch of power which is interpreted as an independent state institution, because its existence is not in the realm of the legislative, executive, or judicial branches of power

Keywords: Position; DKPP; Quasi Ethical Court

\section{PENDAHULUAN}

Dewan Kehormatan Penyelenggara Pemilu (yang selanjutnya disingkat DKPP) merupakan institusi baru yang menjalankan fungsi campuran (mix-function) ${ }^{1}$ yakni fungsi administratif, regulatif, dan penghukuman. Hal ini sesuai jenis lembaga baru yang menjalankan fungsi campuran sebagaimana dinyatakan oleh Jimly Asshiddiqie. ${ }^{2}$

Perubahan Undang-undang Dasar 1945 (selanjutnya disingkat UUD 1945) tidak saja melahirkan berbagai lembaga negara utama, tetapi juga melahirkan berbagai negara pendukung penyelenggaraan pemerintahan. Di bidang yudisial misalnya telah lahir Mahkamah Konstitusi sebagai lembaga negara penyelenggara kekuasaan kehakiman di samping Mahkamah Agung. Di samping dua lembaga tersebut muncul pula lembaga-lembaga yang menjalankan fungsi-fungsi semi yudisial yang kelahirannya tidak disebutkan dalam UUD 1945, tetapi dibentuk melalui

\footnotetext{
1 Jimly Asshiddiqie, Perkembangan dan Konsolidasi Lembaga Negara Pasca Reformasi (Jakarta: Sekretariat Jenderal dan Kepaniteraan Mahkamah Konstitusi RI, 2006), hlm. 339.

2 Ibid.
} 
undang-undang. Salah satu lembaga yang dibentuk dengan undang-undang adalah DKPP yang dibentuk berdasarkan Undang-Undang Nomor 15 Tahun 2011 (selanjutnya disingkat UU No 15 Tahun 2011) tentang Penyelenggara Pemilu, kewenangannya diatur dalam Bab V tentang DKPP Pasal 109 sampai 115 . DKPP merupakan lembaga yang bertugas menangani pelanggaran kode etik penyelenggara pemilu. Penyelenggara pemilu terdiri dari Komisi Penyelenggara Pemilu (KPU) dan Badan Pengawas Pemilu (Bawaslu) sebagai satu kesatuan fungsi penyelenggaraan pemilu untuk memilih anggota Dewan Perwakilan Rakyat (DPR), Dewan Perwakilan Daerah (DPD), Dewan Perwakilan Rakyat Daerah (DPRD), Presiden dan Wakil Presiden, Gubernur, Walikota, dan Bupati secara demokratis. $^{3}$

Keberadaan lembaga-lembaga tersebut menimbulkan berbagai perdebatan konseptual yang serius. Sebagai negara hukum dengan kekuasaan kehakiman yang merdeka sebagai unsur utamanya, maka kekuasaan kehakiman secara teoritis hanya dapat dimiliki oleh lembagalembaga Negara yang secara konstitusional diakui dalam UUD 1945 yaitu Mahkamah Agung dan Mahkamah Konstitusi. Namun di sisi lain perkembangan kehidupan berbangsa dan bernegara yang sedemikian kompleks akibat pengaruh globalisasi dan demokratisasi menyebabkan sebagian urusan kehidupan tidak lagi dapat diselesaikan oleh sebuah lembaga yang bersifat general tetapi dibutuhkan keahlian khusus untuk menyelesaikan masalah hukum yang dihadapi. Itulah kemudian menyebabkan lahirnya Lembaga-lembaga yang disebutkan di atas yang sebenarnya tidak masuk dalam lingkup kekuasaan kehakiman, tetapi menjalankan fungsi-fungsi kekuasaan kehakiman seperti kekuasaan untuk memutus perkara yang memiliki kekuatannya sama dengan putusan pengadilan. $^{4}$

DKPP dibentuk oleh pembuat Undang-Undang yakni Komisi II DPR RI dan pemerintah sebagai solusi terhadap persoalan integritas dari penyelenggara pemilu. Namun awal kemunculan DKPP telah memunculkan kontroversi, khususnya dikalangan penyelenggara pemilu. Penyelengara pemilu yang terdiri dari Komisi Pemilihan Umum (KPU) dan Badan

\footnotetext{
${ }^{3}$ Republik Indonesia, Undang-Undang tentang tentang Penyelenggara Pemilu.UU Nomor 15 Tahun 2011, Pasal 1 angka 5

${ }^{4}$ Jimly Asshiddiqie, Perkembangan dan Konsolidasi Lembaga Negara Pasca

Reformasi (Jakarta: Sekretariat Jenderal dan Kepaniteraan Mahkamah Konstitusi RI, 2006), hlm. 340
} 
Pengawas Pemilu (Bawaslu) bahkan melabeli DKPP sebagai "malaikat pencabut nyawa".

Kehadiran DKPP Prof. Jimly Asshiddiqie dalam kegiatan pembukaan konsolidasi nasional KPU, bahkan pernah disoraki oleh anggota KPU seluruh Indonesia. Sebagaimana yang di tuliskan dalam laman berita online yang menyebut bahwa para anggota KPU daerah yang hadir dalam pembukaan Rapat Konsolidasi Nasional Menyongsong Pemilu 2014 kompak menyoraki Ketua DKPP Jimly Asshiddiqie ketika namanya disebut Ketua KPU Husni Kamil Manik dalam sambutannya ${ }^{5}$

Makna pemilu berkualitas dan berintegritas pada dasarnya telah terangkum dalam pengertian pemilu demokratis yang mensyaratkan minimal dua hal yakni bebas dan adil atau free and fair election. Secara normatif, dalam konstitusi mengatur asas dalam pemilu, yaitu: langsung, umum, bebas, rahasia, jujur dan adil. ${ }^{6}$ Hal ini yang menjadi patokan untuk melihat kualitas dan integritas pemilu di Indonesia.

Asas penyelenggaraan pemilu melahirkan konsep kode etik penyelenggara pemilu. Kode etik diartikan sebagai pola aturan, tata cara, tanda, pedoman etis bagi penyelenggara pemilu dalam melaksanakan kewenangannya. Kode etik diyakini sebagai upaya menginstitusionalisasikan moral dan nilai-nilai sebuah organisasi sehingga kode etik tersebut berperan penting pada perwujudan integritas penyelenggara pemilu.

Penegakan terhadap kode etik penyelenggara pemilu di Indonesia pertama kali dilakukan oleh Badan Pengawas Pemilu (Bawaslu) yang bertugas untuk mengawasi pelaksanaan tahapan pemilu, menerima pengaduan, serta menangani kasus-kasus pelanggaran administrasi, pelanggaran pidana pemilu, serta kode etik. Namun, pada perkembangan terakhir bagian dari fungsi penyelenggaraan pemilu dari aspek penegakan etik dilaksanakan oleh Dewan Kehormatan Penyelenggara Pemilu (DKPP).

DKPP sebelumnya merupakan lembaga yang bersifat ad hoc dengan nama Dewan Kehormatan Komisi Penyelenggara Pemilu (DK KPU), kemudian menjadi lembaga yang bersifat permanen setelah berlakunya UU No. 15 Tahun 2011 Tentang Penyelenggara Pemilu, yang kemudian

\footnotetext{
5 Henni Gusfa dan Irmawanti, Model Peran Peradilan Etik Dalam Meraih Kepercayaan Publik Studi Kasus Penyelenggara Pemilu Berintegritas Dewan Kehormatan Penyelenggara Pemilu Periode 2012-2017, Journal Communication Spectrum, Vol. 7 No. 2 Agustus 2017-Januari 2018. Hal 147

${ }^{6}$ Pasal 22E Ayat (1) Undang-Undang Dasar Negara Republik Indonesia Tahun 1945.
} 
diganti dengan UU No 7 Tahun 2017 Tentang Pemilihan Umum. ${ }^{7}$ Hal ini menjadi langkah yang tepat untuk menegaskan DKPP sebagai institusi etik yang berupaya menjawab pentingnya menjaga kemandirian, integritas, dan kredibilitas penyelenggara Pemilu.

Didasarkan pada wacana membangun pemilu yang berkualitas dan berintegritas, DKPP hadir dalam bentuk penegakan kode etik penyelenggaraa pemilu yakni KPU dan Bawaslu. Hal ni tentunya juga tidak terlepas dari kondisi bahwa penyelenggara Pemilu dengan kewenangan yang dimiliki melakukan praktik-praktik abuse of power untuk menguntungkan diri sendiri atau para pihak yang berkontestasi. Praktikpraktik ketidaknetralan, imparsialitas juga turut mewarnai perilaku penyelenggara saat proses berlangsungnya penyelenggaraan pemilu.

Dalam rangka peningkatan kualitas dan integritas penyelenggaraan pemilu tidak hanya menjadi tanggungjawab dari KPU dan Bawaslu, tetapi juga DKPP yang berperan dalam penegakan etika penyelenggara pemilu. Ketiga lembaga tersebut memiliki tugas masing-masing yang dituntut untuk saling bersinergi. Ketika ketiga lembaga tersebut berselisih dalam pelaksanaan kewenangannya, maka implikasinya adalah pada proses tahapan penyelenggaraan pemilu secara prosedural, maupun secara substansial berkaitan dengan kualitas dan integritas penyelenggaraan pemilu yang tidak berjalan sebagaimana mestinya.

Perjalanan dari DKPP untuk menegakkan etika penyelenggara pemilu tentunya memiliki dinamika tersendiri, baik itu hambatan yang disebabkan karena aturan hukum, maupun implementasi dari aturan hukum tentang etika penyelenggara pemilu, maupun secara umum dalam aturan penyelenggaraan pemilu.

Dalam perjalannya DKPP sejak kehadirannya pada tanggal 12 Juni 2012 yang lalu banyak dinilai masyarakat cukup signifikan terutama dalam kontribusi menegakkan Kode Etik penyelenggara pemilu. Meskipun ada banyak pihak yang masih menganggap terdapat putusan DKPP yang kontroversial dan telah melampui kewenangan yang dimilikinya, misalnya terletak pada putusan DKPP Nomor 23-25/DKPP-PKEI/2012 yang dianggap tidak hanya memutus pengaduan pelanggaran kode etik penyelenggara

\footnotetext{
${ }^{7}$ Republik Indonesia, Undang-undang tentang Pemilihan Umum, UU No 7 Tahun 2017. Lihat juga Republik Indonesia, Undang-Undang tentang tentang Penyelenggara Pemilu.UU Nomor 15 Tahun 2011, Pasal 1 angka 5
} 
pemilu, namun sudah menyentuh ranah teknis tahapan pemilu yang menjadi kewenangan KPU. Disamping itu baru-baru DKPP telah mengeluarkan putusan Nomor 317-PKE-DKPP/X/2019 tentang pemberhentian Evi Novida Ginting Manik sebagai anggota KPU RI karena telah melanggar kode etik. ${ }^{8}$ Putusan pemberhentian Evi Novida Ginting Manik saiga anggota KPU menuai kritikan dari berbagai kalangan. Dan bahkan menjadi menarik dibicarakan lagi ketika Evi Novida Ginting Manik membawa kasus ini ke PTUN dan putusannya mengabulkan gugatan evi dan harus dikembalikan menjadi anggota KPU. Sekalipun obyek gugatan ke PTUN itu adalah keputusan presiden akan tetapi materi muatannya adalah soal pelanggaran etik. Akibat putusan PTUN tersebut seolah-olah mengoreksi Putusan DKPP .

Maka berdasarkan uraian diatas dalam penelitian ini akan meneliti tentang Kedudukan Dewan Kehormatan Penyelenggara Pemilu Sebagai Lembaga Quasi Peradilan Etik. Untuk mengetahu kedudukan dan sifat putusannya sehingga bisa terwujudnya suatu lembaga yang diharapkan dan mampu menjalankan peran dan fungsinya dengan baik dan sesuai dengan peraturan perundang-undangan.

\section{METODE}

Penelitian ini menggunakan metode penelitian hukum yuridis normatif (Normative research) yang berpedoman pada aturan hukum guna menjawab permasalahan yang ada serta menggunakan pendekatan perundang-undangan yang berlaku dan konseptual mengenai masalah yang akan di bahas. Dalam penelitian ini menggunakan bahan hukum primer dan sekunder. bahan hukum primer berupa: Undang-Undang Dasar 1945, Undang-undang Nomor 15 tahun 2011, Undang-Undang Nomor 7 Tahun 2017, Putusan Dewan Kehormatan Penyelenggara Pemilu Nomor 317-PKEDKPP/X/2019 tentang pelanggaran Kode Etik Penyelenggara Pemilu dan putusan Mahkamah Konstitusi nomor 115/PHPU.D-XI/2013. Bahan hukum sekunder dalam penelitian ini terdiri dari buku-buku, jurnal ilmiah dan artikel ilmiah yang dapat memberi penjelasan tentang kedudukan DKPP sebagai lembaga semi peradilan etik. pengumpulan bahan hukum menggunakan studi kepustakaan dan dokumentasi dan analisis bahan hukum dilakukan secara sistematis dengan menggunakan argumentasi

\footnotetext{
${ }^{8}$ Putusan Dewan Kehormatan Penyelenggara Pemilu Nomor 317-PKE-DKPP/X/2019 tentang pelanggaran Kode Etik Penyelenggara Pemilu,hlm 36
} 
hukum secara deduktif dan induktif yang hasil analisisnya dituangkan secara deskriptif dalam artikel ilmiah.

\section{HASIL DAN PEMBAHASAN}

Kedudukan DKPP Sebagai Lembaga Quasi Peradilan Etik

Menurut Bagir Manan dan Kuntana Magnar ${ }^{9}$ dengan adanya kekuasaan kehakiman tidak terlepas dari konsep pemisahan kekuasaan yang dikemukakan oleh Montesqieu yaitu adanya cabang kekuasaan legislatif, eksekutif dan yudikatif. Pemisahan kekuasaan bertujuan supaya tidak kekuasan tersebut tidak ditangan satu personal. Kekuasaan yang di jalankan oleh satu tangan akan menimbulkan terjadinya penyalahgunaan kekuasaan (abuse of power) karena tidak ada mekanisme saling mengkontrol dan keseimbangan antara lembaga negara. Oleh karena itu pada negara yang mengklaim diri dalam konstitusinya sebagai negara hukum. ${ }^{10}$

\section{a. DKPP Sebagai Lembaga Quasi Peradilan Etik}

Untuk mendapatkan kejelasan teoritis keberadaan lembaga quasi peradilan akan diuraiakan beberapa pendapat pakar tentang batasan peradilan. Menurut Sudikno Mertokusumo ${ }^{11}$ peradilan adalah segala seuatu yang bertalian dengan tugas hakim dalam memutus perkara, baik perkara perdata maupun perkara pidana untuk mempertahankan atau menjamin ditaatinya hukum. Menurut Rohmat Soemitro sebuah lembaga dikatakan sebagai peradilan jika memiliki unsur-unsur sebagai berikut :

1) Adanya suatu aturan yang abstrak yang mengikat umum yang dapat diterapkan pada suatu persoalan;

2) Adanya perselihan hukum yang konkrit;

3) Adanya sekurang-kurangnya dua pihak;

\footnotetext{
${ }^{9}$ Bagir Manan dan Kuntana Magnar, 1997, Beberapa Masalah Hukum Tata Negara Indonesia, Edisi Ke-2, Alumni, Bandung, hlm. 39

10 Padmo Wahjono,1986, Indonesia Negara Berdasarkan Atas Hukum, cet ke2, Ghalia Indonesia, Jakarta, hlm.151

${ }^{11}$ Sudkno Mertokusumo, 1971, Sejarah Peradilan dan Perundang-undangannya di Indonesia sejak 1942 dan apakah kemanfaatnya bagi kita bangsa Indonesia, Kilat Maju, Bandung, hlm. 2 Dalam Muh. Risnain, Eksistensi Lembaga Quasi Judisial Dalam Sistem Kekuasaan Kehakiman Di Indonesia : Kajian Terhadap Komisi Pengawas Persaingan Usaha, Jurnal Hukum dan Peradilan, Volume 3, Nomor 1 Maret 2014. Hal 52
} 
4) Adanya suatu aparatur peradilan yang berwenang memutuskan perselisihan; ${ }^{12}$

Menurut Sjahran Basah unsur-unsur peradilan yang disampaikan Rohmat Soemitro di atas perlu ditambah dengan unsur lagi yaitu adanya hukum formal dalam rangka menerapkan hukum (rechstoepassing) dan menemukan hukum (rechvinding) in concreto untuk menjamin ditaatinya hukum materiil.

Berdasarkan pada uraian diatas bahwa unsur tambahan peradilan terhadap pendapat Rohmat Soemitro di atas Sjahran Basah memberikan definisi peradilan adalah "segala sesuatu yang bertalian dengan tugas memutus perkara dengan menerapkan hukum, menemukan hukum "in conreto" dalam mempertahankan dan menjamin ditaatinya hukum materiil dengan menggunakan cara prosedural yang ditetapkan oleh hukum formal. ${ }^{13}$ Aspek lain yang dipandang relevan untuk memahami keberadaan lembaga quasi-yudisial dalam kekuasaan kehakiman di Indonesia adalah pemahaman lembaga quasi yudisial itu sendiri.

Istilah lembaga quasi-judisial di Indonesia diperkenalkan Jimly Asshidiqie dalam Makalah beliau yang berjudul Pengadilan Khusus yang dimuat dalam website pribadi beliau. ${ }^{14}$ Menurut beliau perkembagan kekuasaan kehakiman di Indonesia di era reformasi disamping tumbuh dan berkembangnya pengadilan khusus juga berkembang lembaga-lembaga quasi-pengadilan atau semi-pengadilan. Istilah quasi pengadilan menunjuk pada lembaga-lembaga yang memiliki kewenangan mengadili dan memutus sebuah perkara tetapi sebenarnya bukanlah pengadilan. ${ }^{15}$ Kekuatan putusan Lembaga-lembaga quasi pengadilan sama dengan putusan pengadilan bahkan terdapat putusan lembaga-lembaga tersebut yang putusannya bersifat final and binding sama dengan putusan pengadilan yang bersifat "inkracht". Dengan kewenangan yang begitu luas keberadaaan lembaga quasi-judisial menimbulkan kekhawatiran terjadinya tumpang tindih kewenangan dengan pengadilan yang memiliki

\footnotetext{
${ }^{12}$ Rochmat Sumitro, 1978, Rancangan Undang-Undang Peradilan Administrasi, BPHN, Jakarta, hlm. 9-10. Muh. Risnain, ibid.

${ }^{13}$ Sjahran Basah,1997, Eksistensi dan Tolok Ukur Badan Peradilan Administrasi di Indonesia, Alumni, Bandung, hlm.23-24. Muh. Risnain. Ibid.

14 Muh. Risnain, Eksistensi Lembaga Quasi Judisial Dalam Sistem Kekuasaan Kehakiman Di Indonesia : Kajian Terhadap Komisi Pengawas Persaingan Usaha, Jurnal Hukum dan Peradilan, Volume 3, Nomor 1 Maret 2014. Hal 52 ${ }^{15}$ Ibid.
} 
kekuasaan di bidang kehakiman (judicial power). Fenomena menjamurnya lembaga quasi-judisial dalam khasanah sistem kekuasaan kehakiman Indonesia merupakan hal yang baru, sehingga bangunan teoritis tentang hal ini masih sangat minim. Dengan mengutip pertimbangan pertimbangan putusan Pengadilan Texas dalam kasus Perdue, Brackett, Flores, Utt dan Burns versus Linebarger, Goggan, Blair sebagaimana yang dikutip oleh Jimly Assidiqie dalam makalahnya mengambil beberapa kriteria sebuah lembaga yang dikategorikan sebagai quasi-yudicial yaitu: ${ }^{16}$

1) Kekuasaan untuk memberikan penilaian dan pertimbangan. (The power to exercise judgement and discretion);

2) Kekuasaan untuk mendengar dan menentukan atau memastikan fakta-fakta dan untuk membuat putusan. (The power to hear and determine or to ascertain facts and decide);

3) Kekuasaan untuk membuat amar putusan dan pertimbanganpertimbangan yang mengikat sesuatu subjek hukum dengan amar putusan dan dengan pertimbangan-pertimbangan yang dibuatnya. (The power to make binding orders and judgements);

4) Kekuasaan untuk mempengaruhi hak orang atau hak milik orang per orang. (The power to affect the personal or property rights of private persons);

5) Kekuasaan untuk menguji saksi-saksi, untuk memaksa saksi untuk hadir, dan untuk mendengar keterangan para pihak dalam persidangan. (The power to examine witnesses, to compel the attendance of witnesses, and to hear the litigation of issues on a hearing); dan

6) Kekuasaan untuk menegakkan keputusan atau menjatuhkan sanksi hukuman. (The power to enforce decisions or impose penalties); ${ }^{17}$

Penting juga untuk diperhatikan landasan konstitusional eksistensi lembaga quasi-judisial ini. Pada perubahan konstitusi ya ke-empat pengakuan terhadap keberadaan lembaga quasi-judisial diatur dalam pasal 24 ayat (3) UUD NRI 1945 yang menentukan bahwa "badan badan

\footnotetext{
16 Jimly asshidiqee, Pengenalan Tentang DKPP Untuk Penegak Hukum, hal 6. makalah yang ditulis februari 2013.

http://www.jimly.com/makalah/namafile/120/Pengenalan_DKPP.pdf yang diakses 16 november 2019.

17 Ibid.
} 
lain yang fungsinya berkaitan dengan kekuasaan kehakiman diatur dalam undang-undang".

Ketentuan tersebut menurut hemat penulis mengandung makna, pertama,pengakuan konstitusional terhadap keberadaan lembaga quasijudisial yang telah ada sebelum perubahan konstitusi maupun yang akan dibentuk pada waktu yang akan datang. Penyebutan frase badan-badan pada Pasal 24 ayat (3) UUD NRI 1945 menandakan bahwa telah ada lembaga-lembaga negara yang memiliki kewenangan semi-judisial, seperti Dewan Kehormatan Penyelenggara Pemilu. Konstitusi hanya memberikan landasan konstitusional bagi keberadaan lembaga-lembaga ini dalam sistem kekuasaan kehakiman Kedua, syarat legalitas pendirian lembaga quasi-judisial diatur dalam Undang-undang. Maknanya, lembaga quasijudisial baik yang telah dibentuk maupun yang akan dibentuk harus diatur pada level Undang-undang sebagai bentuk legitimasi konstitusional karena undang-undang merupakan cerminan aspirasi rakyat yang diwakili oleh Presiden dan DPR.

DKPP merupakan Sebagai Pengadilan Etika, ${ }^{18}$ dan merupakan perkembangan lebih lanjut dari lembaga Dewan Kehormatan Komisi Pemilihan Umum (DK-KPU) yang sudah ada sebelumnya yang diatur berdasarkan UU No. 22 Tahun 2007 tentang Penyelenggara Pemilu yang sekarang diubah menjadi UU No 15 Tahun 2011 dan rubah lagi menjadi UU No 7 tahun 2017 tentang pemilihan Umum. Sejak UU No. 22 Tahun 2007 tentang penyelenggaraan pemilihan umum, putusan Dewan Kehormatan dinyatakan bersifat final dan mengikat, sehingga oleh karena itu dapat dikatakan memiliki karakter dan mekanisme kerja seperti lembaga peradilan. Oleh karena itu, sejak terbentuknya DK-KPU pertama kali pada tahun 2009, dimana prof Jimly menjadi ketuanya secara berturut-turut selama tahun 2009 dan 2010, mekanisme kerja Dewan Kehormatan ini didesain sebagai badan peradilan etika yang menerapkan semua prinsip peradilan modern.

Beberapa prinsip penting yang dipraktikkan dalam penyelenggaraan peradilan etik oleh DKPP yang ada sekarang, misalnya, adalah prinsip-prinsip 'audi et alteram partem', prinsip independensi, imparsialitas, dan transparansi. Dengan diberlakukannya prinsip-prinsip tersebut, maka semua pihak yang terkait dengan perkara wajib didengarkan dalam persidangan yang diselenggarakan secara terbuka,

\footnotetext{
${ }^{18}$ Op.cit.
} 
dimana para anggota DKPP bertindak sebagai hakim yang menengahi pertentangan untuk mengatasi konflik dan memberikan solusi yang adil. ${ }^{19}$

Sebagai lembaga quasi yudisial, para anggota DKPP juga bersikap netral, pasif, dan tidak memanfaatkan kasus-kasus yang timbul untuk popularitas pribadi. Para anggota dilarang menikmati pujian yang timbul dari putusan, dan sebaliknya dilarang pula tersinggung atau marah karena dikritik oleh masyarakat yang tidak puas akan putusan DKPP. Pendek kata, sebagai lembaga peradilan etika, DKPP juga harus menjadi contoh mengenai perilaku etika dalam menyelenggarakan sistem peradilan etika yang menyangkut aneka kepentingan yang saling bersitegang antara para peserta pemilu dengan penyelenggara pemilu atau antara masyarakat pemilih (voters) dengan penyelenggara pemilu, ataupun di antara sesama penyelenggara pemilu sendiri, khususnya antara aparat KPU dan Bawaslu.

Konsepsi DKPP sebagai lembaga peradilan etika (court of ethics), secara tegas kemudian dimentahkan oleh MK melalui pertimbangan hukum dalam Putusan MK Nomor 115/PHPU.D-XI/2013, yang menyatakan bahwa "DKPP adalah salah satu organ tata usaha negara bukan bagian dari penyelenggara kekuasaan kehakiman sebagaimana diatur dalam Pasal 24 ayat (2) UUD 1945, dan bukan pula pengadilan khusus sebagaimana dalam penjelasan Pasal 27 ayat (1) UU Nomor 48 Tahun 2009." Oleh karenanya, tidak tepat kemudian DKPP dikonsepsikan sebagai peradilan etika hanya karena menegakkan kode etik berdasarkan prinsip peradilan.

Fungsi kelembagaan DKPP yang dinyatakan sebagai lembaga quasi yudisial, tidak disinggung dalam putusan MK tersebut. Menurut penulis, fungsi quasi yudisial pada DKPP yang berarti menjalankan kewenangan dalam menyelesaikan perkara pelanggaran etik mengunakan metode dan prinsip peradilan. Namun, apabila dikatakan bahwa quasi yudisial membentuk konsep DKPP sebagai peradilan etik, tidak sepenuhnya dapat dianggap benar, karena implikasi dari menyebutkan DKPP sebagai badan peradilan etika adalah pada putusannya layaknya badan peradilan. Sedangkan, untuk menjalan fungsi quasi yudisial, tidak selalu menjadi lembaga dengan putusan layaknya peradilan.

Berdasarkan uraian diatas Secara konsep DKPP juga dapat disebut lembaga semi peradilan karena mengambil peran dan fungsi sebagai lembaga peradilan (quasi peradilan) yang khusus menangani etik penyelenggara pemilu dan mengedepankan tindakan preventif daripada

\footnotetext{
${ }^{19}$ Ibid.
} 
persidangan dan/atau penjatuhan sanksi. DKPP menjalankan quasijudicial fuction juga dapat dimaknai pelaksanaan kewenangan DKPP menurut UU Pemilu dengan sama baiknya atau sama dari segi kualitasnya dengan fungsi yang dijalankan pengadilan pada umumnya, walaupun dari aspek kelembagaan memang berbeda menurut hukum ketatanegaraan di Indonesia.

\section{b. Pandangan Lain Tentang Kedudukan DKPP}

Akan tetapi seiring waktu, kelembagaan negara semakin berkembang yang ditandai dengan bermunculannya berbagai lembaga baru dalam rangka fungsi pelayanan kepada masyarakat. Pada akhirnya, fungsi-fungsi kekuasaan yang biasanya melekat pada fungsi lembaga eksekutif, legislatif dan yudisial, dialihkan menjadi fungsi organ tersendiri yang bersifat independen. Oleh karena itu, dimungkinkan adanya suatu organ negara yang mempunyai fungsi campuran, masingmasing bersifat independen atau quasi independent.

Dengan demikian, hubungan fungsi kekuasaan negara tidak mungkin tidak saling bersentuhan, hubungan lembaga negara saling bergantung satu dengan yang lainnya. Untuk mencegah terjadinya penyalahgunaan kekuasaan dan agar keuasaan negara dapat dibatasi dan dikontrol, maka dibangunlah sistem checks and balances. Oleh karena itu, perkembangan kelembagaan negara tersebut jika dikaitkan dengan teori fungsi kekuasaan negara dan pendapat beberapa ahli, ada beberapa ahli yang mengelompokkan lembaga tersebut dalam domain atau ranah kekuasaan ekskutif atau mengelompokkannya secara tersendiri sebagai cabang kekuasaan keempat.

Terkait dengan badan penyelenggara pemilu dalam fungsi kekuasaan negara, terdapat tiga model badan penyelenggara pemilu seperti yang dirilis oleh IDEA, yaitu Model Independen, Model Governmental dan Model Campuran. ${ }^{20}$ Pada Model Independen, manajemen pemilu ada di negara-negara di mana pemilihan umum diatur dan dikelola oleh badan pelaksana pemilu yang independen dan institusional yang otonom dari cabang eksekutif, memiliki dan mengelola anggaran sendiri. Badan pelaksana pemilu tidak bertanggung jawab kepada kementerian atau departemen. Mayoritas badan pelaksana pemilu yang independen bertanggung jawab kepada legislatif, yudikatif, atau kepala negara. Badan pelaksana pemilu di dalam Model Independen dapat

20 Didik Supriyanto, Menjaga Indepedensi Penyelenggara Pemilu, (Jakarta: Perludem, 2007), hal. 27 
menikmati berbagai tingkat otonomi keuangan dan akuntabilitas, serta berbagai tingkat akuntabilitas kinerja. Negara-negara yang baru berkembang demokrasinya dan negara dalam keadaan perang banyak yang memilih Model Independen manajemen pemilu.

Model Governmental ada di negara-negara di mana pemilu diatur dan dikelola oleh cabang eksekutif melalui pelayanan (seperti Kementerian Dalam Negeri) dan/atau melalui pihak berwenang setempat. Terdapat pula Badan pelaksana pemilu di bawah Model Governmental di tingkat nasional, mereka dipimpin oleh seorang menteri atau PNS dan bertanggung jawab kepada suatu Kabinet Menteri. Dengan pengecualian sangat sedikit mereka tidak memiliki 'anggota'. Anggaran mereka jatuh dalam sebuah pelayanan pemerintah dan / atau di bawah pemerintah daerah.

Dalam model manajemen pemilu campuran, biasanya ada dua komponen badan pelaksana pemilu, dan terdapat struktur ganda: kebijakan, pemantauan atau pengawasan Electoral Management Bodies (EMB) yang independen dari cabang eksekutif pemerintahan (seperti EMB bawah Model Independen) dan implementasi EMB terletak dalam departemen pemerintah negara bagian dan/atau lokal (seperti EMB bawah Model Pemerintah).

Berdasarkan Model Campuran, pemilu yang diselenggarakan oleh EMB komponen pemerintah, dengan beberapa tingkat pengawasan yang disediakan oleh komponen independen EMB. Melaksanakan mandat konstitusi, menyongsong penyelenggaraan Pemilu Tahun 2004, diterbitkan Undang-Undang Nomor 12 Tahun 2003 tentang Pemilu Anggota DPR, DPD dan DPRD yang beberapa pasalnya mengatur penyelenggara pemilu. Mencermati konstruksi Undang-Undang Nomor 12 Tahun 2003, Independen model yang diadopsi konstitusi secara teknis dijabarkan menjadi Mixed Model. Komisioner bersifat independen didukung oleh sekretariat yang berasal dari Pegawai Negeri Sipil Pemerintah Pusat dan Pemerintah Daerah. Model ini dipertahankan pada Undang-Undang Nomor 22 Tahun 2007 dan Undang-Undang Nomor 15 Tahun 2011 tentang Penyelenggara Pemilu.

UU No 15 Tahun 2011 tentang Penyelenggara Pemilu tidak menyebutkan posisi DKPP dalam fungsi kekuasaan negara. Namun jika dimaknai lebih lanjut Pasal 22 E ayat (5) UUD 1945, disebutkan bahwa "Pemilihan umum diselenggarakan oleh suatu komisi pemilihan umum yang bersifat nasional, tetap dan mandiri," maka penulis memahami 
bahwa DKPP merupakan satu kesatuan fungsi dengan "komisi pemilihan umum" yang dinyatakan dalam UUD. Dengan demikian, DKPP merupakan lembaga yang mandiri (independent bodies). ${ }^{21}$

Hal ini berbeda dengan kedudukan Bawaslu yang diperkuat oleh Mahkamah Konstitusi melalui putusannya yang menegaskan bahwa klausul "suatu komisi pemilihan umum" dalam UUD 1945 tidak merujuk kepada sebuah nama institusi, akan tetapi menunjuk pada fungsi penyelenggaraan pemilihan umum yang bersifat nasional, tetap dan mandiri. Dengan demikian, menurut Mahkamah, fungsi penyelenggaraan pemilu tidak hanya dilaksanakan oleh Komisi Pemilihan Umum (KPU), akan tetapi termasuk juga lembaga pengawas pemilihan umum dalam hal ini Badan Pengawas Pemilihan Umum (Bawaslu) sebagai satu kesatuan fungsi penyelenggaraan pemilihan umum yang bersifat nasional, tetap dan mandiri. ${ }^{22}$

Menurut Gunawan A. Tauda mengategorikan suatu lembaga sebagai lembaga negara independen berdasarkan persamaan karakteristik yang dikemukakan beberapa ahli, yaitu (1) William F. Fox Jr., (2) William F. Funk \& Richard H. Seamon, (3) Milakovich, dan (4) Michael R. Asimow. Karakteristik tersebut adalah: ${ }^{23}$

1. Independensi komisi dinyatakan secara tegas oleh pembentuk undang- undang dalam undang-undang komisi tersebut. (Syarat normatif)

2. Independen, dalam artian bebas dari pengaruh, kehendak, ataupun kontrol dari cabang kekuasaan eksekutif. (Syarat condition sine qua non)

3. Pemberhentian dan pengangkatan anggota komisi menggunakan mekanisme tertentu yang diatur khusus, bukan semata-mata berdasarkan kehendak Presiden.

21 Lihat juga Putusan Nomor 81/PUU-IX/2011 bahwa kelembagaan DKPP “... Sebagai satu kesatuan fungsi penyelenggara pemilihan umum, maka menurut Mahkamah sifat mandiri yang dinyatakan dalam Pasal 22E ayat (5) UUD 1945 harus juga mendasari pembentukan dewan kehormatan."

${ }^{22}$ Mahkamah Konstitusi (2), Putusan Nomor 11/PUU-VIII/2010 tentang Pengujian Undang-Undang Nomor 22 Tahun 2007, Pertimbangan Hukum

${ }^{23}$ Gunawan A. Tauda, Komisi Negara Independen; Eksistensi Independent Agencies sebagai Cabang Kekuasaan Baru dalam Sistem Ketatanegaraan, (Yogyakarta: Genta Press, 2012). Hal 99-100 
4. Kepemimpinan kolektif kolegial, jumlah anggota atau komisioner bersifat ganjil dan keputusan diambil secara mayoritas suara.

5. Kepemimpinan tidak dikuasai atau tidak mayoritas berasal dari partai politik tertentu.

6. Masa jabatan para pemimpin komisi definitive, dan tidak habis secara bersamaan, tetapi bergantian (staggered terms).

7. Keanggotaan lembaga biasanya menjaga keseimbangan perwakilan yang bersifat non-partisan. ${ }^{24}$

Secara umum, alat perlengkapan negara yang berupa state auxiliaries atau independent bodies muncul karena: (1) Adanya tugastugas kenegaraan yang semakin kompleks yang memerlukan independensi yang cukup untuk operasionalisasinya. (2) Adanya upaya empowerment terhadap tugas lembaga negara yang sudah ada melalui cara membentuk lembaga baru yang lebih spesifik. ${ }^{25}$

Pembentukan organisasi atau lembaga-lembaga negara yang bersifat independen seperti disebut di atas, menggambarkan terjadinya perubahan besar dan sangat mendasar dalam corak dan susunan organisasi negara dewasa ini. Dewasa ini, corak kelembagaan organisasi negara dengan kompleksitas sistem adminstrasinya sudah sangat jauh berkembang. Lembaga-lembaga ini menjalankan fungsi campuran (mix function) antara fungsi regulatif, administratif, dan penghukuman yang biasanya dipisahkan, namun justru dilakukan secara bersamaan oleh lembaga-lembaga baru tersebut. ${ }^{26}$

Semestinya dalam undang-undang Penyelenggara Pemilu terdapat ketentuan dan pengaturan tentang kedudukan DKPP dalam fungsi kekuasaan negara, untuk memperjelas kedudukan DKPP dalam struktur

24 Istilah "non-partisan" mengacu pada artian keanggotaan yang bukan berasal dari partai atau berhenti dari keanggotaan partai politik. Lihat Ibid, hal.100.

${ }^{25}$ Fatmawati, Struktur dan Fungsi Legislasi Parlemen Dengan Sistem Multikameral: Studi Perbandingan Indonesia dan Berbagai Negara, Disertasi, Universitas Indonesia, 2009, hlm.22. lihat juga Hendra Nurtjahjo, “Lembaga, Badan, dan Komisi Negara Independen di Indonesia: Tinjauan Hukum Tata Negara," Jurnal Hukum dan Pembangunan, Tahun ke-35 No. 3 (Juli- September 2005): 280

${ }^{26}$ Jimly Asshiddiqie, Pengantar Ilmu Hukum Tata Negara, (Jakarta: Rajawali Pers, 2009), hal. 338-339. 
ketatanegaraan Indonesia. Hal ini mengakibatkan timbulnya beberapa penafsiran, diantaranya DKPP berada dalam kekuasaan yudikatif dengan mengacu pada Pasal 24 ayat (3) UUD 1945 atau DKPP tidak berada dalam kekuasaan manapun melainkan dikelompokkan secara tersendiri sebagai cabang kekuasaan keempat.

Penulis berpendapat bahwa fungsi DKPP memang berkaitan dengan kekuasaan kehakiman, tetapi tidak berada di bawah kekuasaan yudisial. Hal ini seperti yang dinyatakan oleh Funk dan Seamon, bahwa lembaga negara independen tidak jarang mempunyai kekuasaan quasi legislative, quasi eksekutif dan quasi judicial power. ${ }^{27}$

DKPP dapat dikelompokkan ke dalam cabang kekuasaan keempat seperti yang dikemukakan oleh Bruce Ackerman dalam teorinya The New Separation of Power, Yves Meny dan Andrew Knapp dalam teorinya The Fourth Branch of the Government, dan Crince le Roy dengan teorinya De Vierde Macht.

Bruce Ackerman dalam tulisannya The New Separation of Power, mengatakan bahwa bentuk terbaru (distinctive pattern) dari paham pemisahan kekuasaan modern tidak lagi terbatas berdasarkan pada pemisahan tiga fungsi saja sebagaimana yang dikehendaki Montesquieu dan Madison, melainkan telah terwujud ke dalam lembaga-lembaga yang ada pada sistem kelembagaan negara itu sendiri. Ackerman mengatakan, cabang-cabang kekuasaan negara hendaknya dengan tegas dilihat berdasarkan model kelembagaannya, yang dalam konteks Amerika Serikat terdiri dari (1) cabang kekuasaan House of Representatives, (2) Senate, (3) President, (4) Supreme Court, dan (5) independent agencies. ${ }^{28}$

Yves Meny dan Andrew Knapp juga memperkenalkan teori The Fourth Branch of The Government sebagai berikut: ${ }^{29}$

"Regulatory and monitoring bodies are a new type of autonomous administration which has been most widely developed in the United States (where it is sometimes referred to as the "headless fourth branch"

${ }^{27}$ William F. Funk and Richard H. Seamon, Adminstrative Law; Examples and Explanations, (New York: Aspen Law \& Bussiness, 2001). Hal 93. Dalam Gunawan A. Tauda, Komisi Negara Independen; Eksistensi Independent Agencies sebagai Cabang Kekuasaan Baru dalam Sistem Ketatanegaraan, (Yogyakarta: Genta Press, 2012). Hal 99

${ }^{28}$ Ibid . hal. 107

${ }^{29}$ Ibid. 
of the government). It take the form of what are generally known as Independent Regulatory Commissions". ${ }^{30}$

Cabang kekuasaan keempat yang dimaksud dalam teori di atas, dapat pula mengambil bentuk atau dimaknai sebagai lembaga negara independen, karena keberadaannya tidak berada dalam ranah cabang kekuasaan legislatf, eksekutif, ataupun cabang yudisial.

Sementara itu, Crince le Roy juga berpendapat bahwa terdapat kekuasaan lainnya di samping tiga kekuasaan negara; eksekutif, legislatif dan yudisial. Kekuasaan tersebut yaitu komisikomisi independen, pers, aparat kepegawaian, kekuasaan-kekuasaan pengawasan, komisi-komisi pelayanan masyarakat, rakyat yang memiliki hak pilih, kelompok-kelompok penekan dan partai-partai politik.

Sistem kekuasaan tersebut merupakan sistem yang terbuka. Setiap lembaga yang bekerja dalam tahap proses penertiban dilengkapi dengan kekuasaan mengambil keputusan dan turut menentukan kebijakan, maka badan tersebut merupakan kekuasaan. Sehingga diperoleh gambaran yang jelas tentang pusat-pusat dalam negara, di mana keputusan-keputusan tersebut diambil. Maka, sistem checks and balances merupakan sistem yang tepat. Menurut Roy, apabila kekuasaan tetap dilihat sebagai kekuasaan menurut doktrin Montesquieu dengan segala hal yang abstrak yang melekat padanya, maka tidak dapat diperoleh sistem checks and balances yang optimal. ${ }^{31}$

Berdasarkan pemaparan di atas, penulis memberanikan diri untuk mengkategorikan DKPP sebagai cabang kekuasaan keempat, bersamasama dengan KPU dan Bawaslu sebagai badan penyelenggara pemilu. Posisi DKPP sebagai supporting organ dari KPU dan Bawaslu akan semakin berpengaruh jika sistem checks and balances berjalan dengan baik. Dengan adanya sistem checks and balances tersebut, badan-badan penyelenggara pemilu dapat terjaga keintegritasannya.

DKPP dibentuk dengan undang-undang. Di sebagian besar negara lain, badan penyelenggara pemilu juga dibentuk dengan undang-undang. hal ini sudah cukup tepat mengingat kedudukan DKPP sebagai salah satu

30 Yves Meny dan Andrew Knapp, Government and Politic in Western Europe: Britain, France, Italy, Germany, $3^{\text {rd }}$ Edition, (Oxford: Oxford University Press, 1998). Dalam Gunawan A. Tauda, ibid.

31 Ibid. hal 363 
lembaga mandiri. Namun untuk fungsi kekuasaan penyelenggara pemilu perlu dipertegas dalam konstitusi sebagai cabang kekuasaan keempat di Indonesia.

\section{c. Sifat Putusan DKPP}

Berdasarkan Pasal 112 ayat (12) UU No 15 Tahun 2011 sebagaimana diubah menjadi UU No 7 tahun 2017 tentang pemilihan umum menyatakan putusan DKPP bersifat final and binding, artinya tidak ada ruang untuk menilai atau menginterpretasikan Putusan DKPP. Ketentuan tersebut, dipertegas lagi dalam Pasal 39 ayat 1 Peraturan Dewan Kehormatan Penyelenggara Pemilu Nomor 3 Tahun 2017 tentang Pedoman Beracara Kode Etik Penyelenggara Pemilu. ${ }^{32}$

Frasa final and binding dalam putusan DKPP, mewajibkan KPU dan Bawaslu untuk segera melaksanakan putusan DKPP paling lama 7 hari sejak putusan dibacakan. Walaupun secara konseptual dan yuridis putusan DKPP melampaui kewenangan yang dimilikinya (menegakkan kode etik penyelenggara Pemilu).

Salah satunya, Putusan DKPP Nomor 83/DKPP-PKE-II/2013 dan Nomor 84/ DKPP-PKE-II/2013, yang memerintahkan kepada KPU Provinsi Banten untuk memulihkan dan mengembalikan hak konstitusional bakal pasangan calon Arief R. Wismansyah-Sachrudin dan bakal pasangan calon Ahmad Marju Kodri-Gatot Suprijanto. Meskipun secara konseptual dan yuridis DKPP tidak memiliki kewenangan memulihkan hak konstitusional bakal pasangan calon, tapi KPU Provinsi Banten diharuskan melaksanakan putusan DKPP karena bersifat final and binding.

Putusan Mahkama Konstitusi Nomor 115/PHPU.D-XI/2013, yang memberikan tafsir terhadap keabsahan dan konstitusionalitas putusan DKPP yang melampaui kewenangannya, adalah putusan yang cacat hukum dan tidak wajib diikuti, menunjukkan bahwa putusan DKPP yang bersifat final and binding menimbulkan efek psikologis bagi jajaran KPU serta Bawaslu berupa ketakutakan akan sanksi pemecatan atau pemberhentian sementara dan berpotensi menimbulkan polemik hukum yang berkepanjangan. Sifat putusan DKPP yang final and binding juga

\footnotetext{
32 Lihat peraturan dewan kehormatan penyelenggara pemilu nomor 3 tahun 2017 tentang pedoman beracara kode etik penyelenggara pemilu.
} 
menegaskan kewenangan pembinaan dan supervisi yang dimiliki KPU dan Bawaslu. ${ }^{33}$

Putusan DKPP yang lain misalnya putusan Nomor 317-PKEDKPP/X/2019 tentang pemberhentian Evi Novida Ginting Manik sebagai anggota KPU RI karena telah melanggar kode etik. Dan putusan tersebut menjadi kontroversial ketika PTUN mengeluarkan putusan atas gugatan Evi Novida Ginting Manik dikabulkan oleh PTUN. Dengan keluarkan putusan tersebur menjadi tamparan keras bagi DKPP sekalipun obyek gugatan ke PTUN bukanlah putusan DKPP tetapi Keputusan presiden. Hal demikian juga diakibatkan karena putusan DKPP final and bilding padahal DKPP sendiri adalah organ tata usaha negara sebagaimana dijelaskan dalam putusan Mahkamah konstitusi Nomor 115/PHPU.D-XI/2013 yang artinya bahwa setiap putusan DKPP bisa di gugat ke PTUN.

DKPP juga bukanlah lembaga yang menjalankan kekuasaan kehakiman sebagaimana merujuk ketentuan Pasal 24 Undang-Undang Dasar Negara Republik Indonesia Tahun 1945, sehingga putusan DKPP yang bersifat final and binding tidak dapat dipersamakan dengan putusan lembaga peradilan yang bersifat final dan mengikat. Seharusnya putusan DKPP hanya bersifat rekomendasi dan tidak bersifat final and binding karena memerlukan persetujuan administrasi lebih lanjut dari KPU dan Bawaslu. Sifat putusan yang final and binding telah membuat DKPP menjadi lembaga superior dan menghilangkan prinsip checks and balances di antara lembaga yang terkait dengan penyelenggaraan Pemilu. ${ }^{34}$ Oleh karena itu, penting untuk parmeninjau kembali rumusan frasa inal and binding dalam skema putusan DKPP, sekaligus menyediakan saluran hukum untuk menguji putusan Dewan Kehormatan Penyelenggara Pemilu.

Belakangan MK melalui Putusan Nomor 31/PUU-XI/2013, ${ }^{35}$ menyatakan bahwa putusan DKPP yang bersifat final dan mengikat sebagaimana dimaksud dalam Pasal 112 ayat (12) UU No 15 Tahun 2011sebagaimana diubah menjadi undang-undang no 7 tahun 2017 tentang pemilu, dapat menimbulkan ketidakpastian hukum dan tidak dapat

33 Irvan Mawardi, Dinamika Sengketa Administrasi di Pemilukada, Yogyakarta: Rangkang Education, 2014. Hal 290

34 Zaki Mubaroq, Kedudukan DKPP dalam Sistem Ketatanegaraan Indonesia, Lampung:Pasca Sarjana Ilmu Hukum Universitas Lampung, 2013, hal 96. Dalam Muh. Salman Darwis, Implementasi Kewenangan DKPP Pasca Putusan Mahkamah Konstitusi Nomor 115/PHPU.D-XI/2013, Jurnal Konstitusi, Volume 12, Nomor 1, Maret 2015. Hal 89

${ }^{35}$ Lihat juga Putusan Mahkama Konstitusi Nomor 31/PUU-XI/2013. Hal 75 
disamakan dengan putusan final dan bilding dari lembaga peradilan pada umumnya oleh karena DKPP adalah perangkat internal penyelenggara Pemilu yang diberi wewenang oleh Undang-Undang. Menurut Mahkama Konstitusi sifat final dan mengikat dari putusan DKPP haruslah dimaknai final dan mengikat bagi Presiden, KPU, KPU Provinsi, KPU Kabupaten/Kota, maupun Bawaslu dalam melaksanakan putusan DKPP. ${ }^{36}$

Adapun keputusan Presiden, KPU, KPU Provinsi, KPU Kabupaten/Kota, maupun Bawaslu adalah merupakan keputusan pejabat TUN yang bersifat konkrit, individual, dan inal yang dapat menjadi objek gugatan di PTUN. Berdasarkan Putusan MK Nomor 31/PUU-XI/2013 tersebut, maka secara mutatis mutandis PTUN memiliki kewenangan untuk memeriksa atau menilai kembali putusan DKPP yang menjadi dasar pembuatan keputusan pejabat tata usaha negara

Kembali pada pokok masalah yang dibahas dalam bagian ini adalah tentang kedudukan Dewan Kehormatan Penyelenggara Pemilu Sebagai Quasi peradilan Etik, bahwa DKPP merupakan produk wacana perbaikan kualitas demokrasi khususnya pada penyelenggaraan pemilu. Pemilu seolah menjadi beban sejarah politik tersendiri dan ada tuntutan untuk setiap proses perubahan menuju kearah yang lebih baik. Masuknya dimensi etika dalam penyelenggaraan pemilu menandakan dilakukan perubahan kearah yang lebih baik tersebut. Hal ini dilakukan dengan tujuan menciptakan iklim proses dan hasil yang berintegritas dalam penyelenggaraan pemilu sehingga menghasilkan pemimpin yang berkualitas dan berintegritas pula.

DKPP menjadikan nilai (value) etika sebagai suatu sistem norma yang bisa dipercayai masyarakat. Penegakan etika merupakan pendukung penegakan hukum. DKPP sebagai instrument control social dalam penyelenggaraan pemilu. Dalam pandangan masyarakat, sebagai Institusi penegakan etika DKPP disebut sebagai The Believed Capacity of Any Object To Statistfy Human Desire. Kelahiran lembaga ini sebagai salah satu instrumen dari perwujudan demokrasi substansial yang mencitrakan dirinya dengan nilai kebaikan bersama tanpa keberpihakan. ${ }^{37}$

\footnotetext{
${ }^{36}$ Muh. Salman Darwis, Implementasi Kewenangan DKPP Pasca Putusan Mahkamah Konstitusi Nomor 115/PHPU.D-XI/2013, Jurnal Konstitusi, Volume 12, Nomor 1, Maret 2015. Hal 89

37 Jimly Asshiddiqie, Menegakkan Etika Penyelenggara Pemilu, Raja Grafindo, Jakarta, 2013, hlm. 87.
} 
Secara umum, poin penting dari dinamika pelaksanaan kewenangan DKPP sebagaimana diuraikan sebelumnya, bahwa kewenangan DKPP dalam menyelesaikan perkara pelanggaran kode etik dengan putusan yang bersifat final dan mengikat. isu penting tersebut direspon oleh MK melalui Putusan No. 11/PUU-VII/2010 dan Putusan No. 31/PUU-XI/2013.

Sejalan dengan hal tersebut, berkaitan dengan sifat putusan DKPP, MK menegaskan dalam Putusan Nomor 31/PUU-XI/2013, ${ }^{38}$ dengan menyatakan bahwa sifat putusan final dan mengikat DKPP hanya kepada Presiden, KPU, dan Bawaslu. Hal ini didasarkan pada DKPP yang bukan merupakan badan peradilan dengan sifat putusan final dan mengikat bagi semua pihak. Salahsatu prinsip penting yang kemudian diluruskan oleh MK dalah putusannya adalah terkait keputusan Presiden, KPU, dan Bawaslu yang melaksanakan putusan DKPP adalah bagian dari objek sengketa tata usaha negara yang menjadi kompetensi PTUN.

Apabila DKPP sebagai lembaga peradilan, tentunya keputusan pelaksana atas putusan peradilan yang dikeluarkan oleh Presiden, KPU dan Bawaslu sebagai pejabat tata usaha negara tidak dapat lagi diuji ke pengadilan karena keputusan tersebut hanya bersifat formalitas dalam rangka menjalankan putusan peradilan. Melalui Putusan MK Nomor 31/PUU-XI/2013, putusan DKPP sejajar dengan keputusan Presiden, KPU, dan Bawaslu sebagai keputusan tata usaha negara. Hal ini memunculkan beberapa catatan tersendiri yaitu: pertama, pengujian yang dilakukan oleh PTUN tidak secara langsung menguji putusan DKPP karena tidak ada kewenangan PTUN untuk menguji putusan DKPP sebelum dituangkan dalam keputusan Presiden, KPU, dan Bawaslu.

Kedua, jika melihat dari pengaturannya, produk dari kewenangan DKPP dalam memutuskan perkara pelanggaran kode etik penyelenggara pemilu adalah "putusan". Dalam teori norma hukum, dikenal 3 jenis norma, yaitu, peraturan perundang-undangan, keputusan, dan putusan. Masing-masing dari jenis norma hukum tersebut berbeda sifatnya dan berbeda organ yang mengeluarkannya. peraturan perundang-undangan yang sifatnya regeling, dibentuk oleh lembaga legislatif (dalam konteks Indonesia dibentuk secara bersama dengan eksekutif). Keputusan dikeluarkan oleh pejabatan tata usaha negara yang sifatnya beschikking

${ }^{38}$ Lihat putusan Mahkama konstitusi Nomor 31/PUU-XI/2013 
secara final, individual dan konkrit. Putusan dikeluarkan oleh lembaga peradilan. ${ }^{39}$

Secara kelembagaan, DKPP maupun lembaga peradilan umum adalah fungsi mengadili. DKPP menerapkan hukum, dalam peraturan perundang-undangan (asas legalitas formal maupun materiil) yaitu: Peraturan DKPP. Fakta yang diajukan kepada DKPP dapat diartikan bahwa DKPP mengadili dengan menerapkan administrative policy atau suatu kebijakan formulatif. ${ }^{40}$ Namun disisi lain, berdasarkan teori norma hukum, maka tidak tepat jika produk hukum yang dikeluarkan DKPP dalam menyelesaikan perkara disebut dengan "putusan", karena DKPP bukan sebagai lembaga peradilan yang menghasilkan produk hukum putusan. DKPP adalah badan tata usaha negara yang seharusnya mengeluarkan produk hukum "keputusan”. Fungsi peradilan atau quasi peradilan hanya menjadi cara bagi DKPP dalam melahirkan keputusan atas pemeriksaan perkara pelanggaran kode etik penyelenggara pemilu.

Ketiga, pengujian keputusan Presiden, KPU dan Bawaslu sebagai pelaksana dari putusan DKPP oleh Pengadilan Tata Usaha Negara, menurut penulis justru tidak memberikan kepastian hukum dan menjadikan penyelesaian perkara dalam jangka waktu yang relatif lama. Ilustrasi yang dapat dijadikan contoh adalah ketika pengujian keputusan Presiden, KPU dan Bawaslu yang didasarkan pada putusan DKPP dilakukan oleh PTUN, kemudian berakhir pada pembatalan keputusan tersebut. Maka muncul beberapa permasalahan: 1) apa materi yang diperiksa oleh PTUN karena keputusan Presiden, KPU dan Bawaslu hanya formalitas untuk menetapkan putusan DKPP; 2) Putusan PTUN yang membatalkan keputusan Presiden, KPU dan Bawaslu tidak serta merta kemudian membatalkan pula putusan DKPP; dan 3) Putusan DKPP yang dianggap masih berlaku adalah produk hukum yang kosong tanpa pernah bisa dieksekusi oleh Presiden, KPU dan Bawaslu.

Peneliti sepenuhnya mengamini dan sepakat dengan putusan Mahkama Konstitusi yang mendudukan DKPP baik itu dari kelembagaannya dan kewenangannya dalam sistem ketatanegaraan di Indonesia, khususnya penegakan kode etik penyelenggara pemilu. Namun, diperlukan langkah hukum lebih lanjut untuk dapat menerapkan putusan MK tersebut dalam

39 Jimly Asshiddiqie, Hukum Tata Negara Dan Pilar-Pilar Demokrasi, Jakarta, Konstitusi Press, 2005, hlm. 5-7.

${ }^{40}$ Muhammad dan Teguh Prasetyo, Eksistensi DKPP RI Dalam Mengawal Demokrasi dan Pemilu bermartabat, Rajawali Pers, Jakarta, 2018, hlm. 60. 
peraturan perundang-undangan. Maka, DKPP harus dimurnikan menjadi organ tata usaha negara yang bertugas menyelesaikan perkara pelanggaran kode etik dengan mengubah produk hukum DKPP dari yang sebelumnya adalah "putusan" menjadi "keputusan". Perubahan tersebut akan memberikan kepastian dalam hal pengujian keputusan DKPP sebagai kompetensi PTUN. Selain itu pula, hendaknya PTUN adalah peradilan tingkat pertama dan terakhir untuk memutuskan perkara yang berkaitan dengan kode etik penyelenggara pemilu setelah DKPP, dengan kewenangan menguji keputusan DKPP. Sehingga, keputusan Presiden, KPU, dan Bawaslu nantinya adalah keputusan pelaksana dari putusan peradilan, yaitu PTUN.

\section{PENUTUP}

Berdasarkan pembahasan di atas maka dapat ditarik kesimpulan bahwa kedudukan DKPP sebagai lembaga quasi peradilan etik khusus untuk penyelenggara pemilu yaitu Bawaslu, dan KPU, akan tetapi kedudukannya tidak berada di bawah kekuasaan kehakiman sebagaimana keputusan Mahkamah Konstitusi nomor 115/PHPU.D-XI/2013, yang menyatakan bahwa DKPP adalah salah satu organ tata usaha negara bukan bagian dari penyelenggara kekuasaan kehakiman sebagaimana diatur dalam Pasal 24 ayat (2) UUD 1945, dan bukan pula pengadilan khusus sebagaimana dalam penjelasan Pasal 27 ayat (1) UU Nomor 48 Tahun 2009. Maka dalam struktur lembaga negara kedudukan DKPP adalah sebagai Cabang kekuasaan keempat yang dimaknai sebagai lembaga negara independen, karena keberadaannya tidak berada dalam ranah cabang kekuasaan legislatif, eksekutif, ataupun cabang yudisial.

Berdasarkan uraian hasil penelitian yang telah disimpulkan diatas, penulis mengajukan beberapa saran kepada Pemerintah dan DPR untuk merevisi UU Nomor 7 Tahun 2017 tentang Pemilihan Umum, khususnya yang mengatur terkait kelembagaan DKPP dengan mengkonstruksi kelembagaan DKPP secara tegas sebagai lembaga negara independen dalam penegakan etik penyelenggara pemilu. 


\section{DAFTAR PUSTAKA}

\section{Buku-Buku}

Asshiddiqie Jimly,2009, Pengantar IImu Hukum Tata Negara,Jakarta: Rajawali Pers.

, 2013, Menegakkan Etika Penyelenggara Pemilu, Jakarta: Raja Grafindo.

, 2014, Peradilan Etik Dan Etika Konstitusi,Jakarta: Sinar Grafika.

, 2005, Hukum Tata Negara Dan Pilar-Pilar Demokrasi, Jakarta, Konstitusi Press.

Indah Harlina,2008, Kedudukan dan Kewenangan KPK dalam Penegakan Hukum, Jakarta: Disertasi Fakultas Hukum Universitas Indonesia. Irvan Mawardi, 2014, Dinamika Sengketa Administrasi di Pemilukada, Yogyakarta: Rangkang Education.

Gunawan A. Tauda, 2012,Komisi Negara Independen; Eksistensi Independent Agencies sebagai Cabang Kekuasaan Baru dalam Sistem Ketatanegaraan, Yogyakarta: Genta Press.

Muhammad dan Teguh Prasetyo, 2018,Eksistensi DKPP RI Dalam Mengawal Demokrasi dan Pemilu bermartabat, Jakarta: Rajawali Pers.

Supriyanto Didik,2007, Menjaga Indepedensi Penyelenggara Pemilu,Jakarta: Perludem.

\section{Jurnal/artikel}

Asshidiqee Jimly, februari 2013, Pengenalan Tentang DKPP Untuk Penegak Hukum, makalah yang ditulis http://www.jimly.com/makalah/namafile/120/Pengenalan_DKP P.pdf yang diakses 16 November 2019.

Lalu Kukuh Sekartadi, Kewenangan Dewan Kehormatan Penyelenggara Pemilu (DKPP) Mengubah Keputusan KPUD Jawa Timur (Studi Kasus Putusan No. 74/DKPP-PKE-II/2013, Jurnal IUS, Vol 3, No. 8, Agustus 2015. 
Muh. Salman Darwis, Implementasi Kewenangan DKPP Pasca Putusan Mahkamah Konstitusi Nomor 115/PHPU.D-XI/2013, Jurnal Konstitusi, Volume 12, Nomor 1, Maret 2015.

Zaki Mubaroq, Kedudukan DKPP dalam Sistem Ketatanegaraan Indonesia, Lampung:Pasca Sarjana Ilmu Hukum Universitas Lampung, 2013.

Hendra Nurtjahjo (1), "Lembaga, Badan, dan Komisi Negara Independen di Indonesia: Tinjauan Hukum Tata Negara," Jurnal Hukum dan Pembangunan, Tahun ke-35 No. 3 Juli- September 2005.

Muh. Risnain, Eksistensi Lembaga Quasi Judisial Dalam Sistem Kekuasaan Kehakiman Di Indonesia : Kajian Terhadap Komisi Pengawas Persaingan Usaha, Jurnal Hukum dan Peradilan, Volume 3, Nomor 1 Maret 2014.

Henni Gusfa dan Irmawanti, Model Peran Peradilan Etik Dalam Meraih Kepercayaan Publik Studi Kasus Penyelenggara Pemilu Berintegritas Dewan Kehormatan Penyelenggara Pemilu Periode 2012-2017, Journal Communication Spectrum, Vol. 7 No. 2 Agustus 2017-Januari 2018.

\section{Peraturan perundang-undangan/ putusan MK}

Undang-Undang Dasar Negara Republik Indonesia Tahun 1945. , undang-undang tentang tentang pemilihan Umum, UU No 7 tahun 2017.

Republik Indonesia, Peraturan Dewan Kehormatan Penyelenggara Pemilihan Umum Nomor 2 Tahun 2017 Tentang Kode Etik Dan Pedoman Perilaku Penyelenggara Pemilihan Umum. Berita negara tahun 2017 nomor 1338

Peraturan Dewan Kehormatan Penyelenggara Pemilu Nomor 3 Tahun 2017

Tentang Pedoman Beracara Kode Etik Penyelenggara Pemilu.

Mahkamah Konstitusi (2), Putusan Nomor 11/PUU-VIII/2010 tentang Pengujian Undang-Undang Nomor 22 Tahun 2007

Putusan Mahkama Konstitusi Nomor 81/PUU-IX/2011

Putusan Mahkama Konstitusi Nomor 31/PUU-XI/2013 